DOI: 10.31548/machenergy.2019.01.033-038

UDC 339.13:656.025.4/.6(477)

\title{
ANALYSIS OF FREIGHT TRANSPORT MARKET IN UKRAINE
}

\author{
O. M. Zagursky
}

National University of Life and Environmental Sciences of Ukraine, Ukraine.

Corresponding authors: zagurskiy_oleg@ukr.net.

Article history: Received: March 2019. Received in the revised form: April 2019. Accepted: June 2019.

Bibl. 7, fig. 3, tabl. 5 .

Abstract. Transport organizations act in the commodity sector markets as entities offering specific goods such as transport services that form their own freight transport market, which is imposed on other markets. The state of the freight transport market in Ukraine depends on three main factors. They are foreign trade turnover, gross domestic product and production. When all these indicators grow, logistics also develops along with transport in the line of ascent.

The article provides a comprehensive analysis of the freight market in Ukraine. The statistical survey of transportation of products of the economic sectors shows that the distance of cargo transportation is determined by the nature of spatial distribution of specific types of cargo turnover production, as an indicator of the total movement of goods, taking into account their weight and transportation distances.

The results of the freight market analysis indicate that it is heterogeneous and can be segmented by quantity, cargo turnover and transportation distance.

Key words: cargo, transportation, market, commodity turnover, transport services.

\section{Introduction}

Commodity sector markets are formed both by the products of relevant branches of national economies and transnational corporations, with freight transport being the constituent part and the connecting link in many cases.

\section{Formulation of problem}

Transport organizations act in the commodity sector markets as entities offering specific goods such as transport services that form their own freight transport market, which is imposed on other markets. Moreover, unlike other services, transport services cannot be exported, they can be provided only in a certain territory. Therefore, the spectrum of transport service market problems is much wider, and the task of creating the necessary infrastructure is much more complicated than for other sector markets.

\section{Analysis of recent research results}

Some aspects of the analysis and evaluation of sector markets and the transport market are also reflected in the works of J. Allen, M. Brown, T. Cherret [1], M. Girsky [2], V. Zamlynsky, V. Koval, V. Kotlubay [3] A. Efimenko [4], O. Parubets [6], P. Popovych, O. Shevchuk, A. Matviishyn, V. Lototska [7] and other authors.

However, the breadth of tasks that are allotted to the freight transport market and the complexity of their solution require further research in this direction.

\section{Purpose of research}

The aim of the work is to assess the level of demand and supply in Ukrainian freight transport market and to analyze cargo transportation in Ukraine.

\section{Results of research}

The structure of the freight transport service market is influenced by three groups of factors associated with globalization trends and inter-sectoral and intraeconomic factors of economic development.

The first group includes indicators related to the liberalization of trade and economic relations, from the simplification of international trade by reducing domestic tariffs, up to the complete elimination of customs barriers in mutual trade. Globalization of markets and integration at the mega-level and, accordingly, the emergence of transnational companies (TNCs), generally eliminate or significantly reduce competition between business entities. The second group is represented by macroeconomic factors of the development of the national economy, quantitative and qualitative indicators of the level of demand for freight transport services of the national economy sectors. They directly affect the level of consumer activity - economic agents and households.

The third group is a set of indicators that characterize the level of satisfaction of goods and services manufacturers with transport services available in the market for goods transportation and the conditions 
for interaction between market entities. When exploring sector markets, it should be born in mind that companies that offer their products to them in many other circumstances are influenced by at least two forces: direct competitors and consumers. Therefore, in the analysis it is fair to use exactly the asymmetry of information between the seller and the buyer on the parameters of the market. As only in this scenario it is possible to conduct a comprehensive market analysis and to develop an effective state policy on the competitive interaction of business entities. In the analysis of the freight transport market in the transport system, the following modes of transport are distinguished:

$$
\begin{aligned}
& \text { - railway, } \\
& \text { - road, } \\
& \text { - marine, } \\
& \text { - river, } \\
& \text { - pipeline, } \\
& \text { - air. }
\end{aligned}
$$

Each of these modes of transport has its advantages and disadvantages, which depend on economic factors and conditions both in a particular country and in the world economy. The share of transport in world GDP varies from 4 to $9 \%$. Annually, over 100 billion tons of cargo and more than 1 trillion passengers are transported by all modes of transport in the world. Except marine transport, more than 650 million cars, 10 thousand airplanes, 200 thousand locomotives [5] take part in the transportation mentioned. Therefore, the assessment of the transport market state is done with all modes of transport taken into account.

The estimation of the number of transported cargoes by modes of transport in million tons (Table 1), shows the total predominance of road transport over other types (the share of automobile transport in the total number of transported cargoes during the years of analysis from 67 to $71 \%$ ).

Table 1. Transportation of goods by modes of transport (million tons).

\begin{tabular}{|l|c|c|c|c|c|}
\hline & 2013 & 2014 & 2015 & 2016 & 2017 \\
\hline Transport total & 1802 & 1623 & 1474 & 1543 & 1582 \\
\hline railway & 436 & 386 & 350 & 343 & 339 \\
\hline marine & 3 & 3 & 3 & 3 & 2 \\
\hline river & 3 & 3 & 3 & 4 & 4 \\
\hline road & 1236 & 1131 & 1021 & 1086 & 1122 \\
\hline air & 0,1 & 0,1 & 0,1 & 0,1 & 0,1 \\
\hline pipeline & 125 & 100 & 97 & 107 & 115 \\
\hline
\end{tabular}

Source: Transport and communications in Ukraine, 2017: collected papers, ed. by O.O. Karmazin. Kyiv: State Statistics Service of Ukraine, 2018. p. 154.

However, weighing on the fact that the product of the freight transport is the finite specific cargo transportation at specific distances, the traffic volume indicator in tons cannot serve as an unambiguous assessment of a particular mode of transport in the freight transport market. An adequate assessment of the freight transport market can be given only by the indicator of cargo turnover, as an indicator of the total cargo transportation, taking into account their weight and transportation distances.
Analysis of the transport market by the cargo turnover indicator (Table 2) shows that the cargo transportation market in the years 2013-2017 is close to the oligopolistic market, where railway transport is a key element with its share in the total cargo turnover ranging from 54 to $59 \%$, pipeline (23-29\%) and road (14-17\%) modes of transport are regarded as competitors. The contribution of other modes of transport in this indicator of the market is insignificant.

Table 2. Cargo turnover by modes of transport (billion tkm).

\begin{tabular}{|l|c|c|c|c|c|}
\hline & 2013 & 2014 & 2015 & 2016 & 2017 \\
\hline Transport total & 393,3 & 353,6 & 334,7 & 344,2 & 364,2 \\
\hline railway & 219,5 & 210,2 & 195,1 & 187,6 & 191,9 \\
\hline marine & 3,2 & 4,1 & 3,9 & 2,5 & 2,9 \\
\hline river & 1,4 & 1,3 & 1,6 & 1,5 & 1,4 \\
\hline road & 57,4 & 56,0 & 53,3 & 58,0 & 62,3 \\
\hline air & 0,3 & 0,2 & 0,2 & 0,2 & 0,3 \\
\hline pipeline & 111,4 & 81,8 & 80,7 & 94,4 & 105,4 \\
\hline
\end{tabular}

Source: Transport and communications in Ukraine, 2017: collected papers, ed. by O.O. Karmazin. Kyiv: State Statistics Service of Ukraine, 2018. p. 154.

By transportation distances (Table 3), an absolute leader is air transport $(48-53 \%$ of the total distance travelled) followed by sea $(14.5-22.9 \%)$ and pipeline (12.9-15.8\%).

However, to explain the share of the mode of transport dpl in the freight transport market, equation (1) should be considered as an information model, and dp and $\beta 1$ as factors that determine it.

$$
d_{p l}=d_{p} \times \beta_{l},
$$

where: $d_{p}$ is the share of the mode of transport in the total volume of transportation; $\beta_{1}$ is the relative average transportation distance, which is the ratio of the average 
transportation distance of the mode of transport to the

total average distance of all transportation.

Table 3. Average distance of transportation of a ton of cargo by separate mode of transport (km).

\begin{tabular}{|l|c|c|c|c|c|}
\hline & 2013 & 2014 & 2015 & 2016 & 2017 \\
\hline Transport total & 5621 & 6342 & 6163 & 5770 & 6519 \\
\hline railway & 506 & 544 & 557 & 546 & 565 \\
\hline marine & 941 & 1452 & 1173 & 837 & 1264 \\
\hline river & 488 & 432 & 498 & 402 & 391 \\
\hline road & 47 & 49 & 52 & 53 & 56 \\
\hline air & 2753 & 3044 & 3053 & 3048 & 3325 \\
\hline pipeline & 886 & 821 & 830 & 884 & 918 \\
\hline
\end{tabular}

Source: Transport and communications in Ukraine, 2017: collected papers, ed. by O.O. Karmazin. Kyiv: State Statistics Service of Ukraine, 2018. p. 56.

Therefore, when comparing the structure of the turnover index with the structure of the indicator of transportation of products in the freight transport market, it is important to consider the following relationships:
- the share of a specific mode of transport in the total volume of cargo turnover (Table 4).

- the relative level of the average distance the transportation was carried out (Table 5).

Table 4. Fraction of the transport mode in the total volume of transportation $\left(d_{p}\right), \%$.

\begin{tabular}{|c|c|c|c|c|c|}
\hline & 2013 & 2014 & 2015 & 2016 & 2017 \\
\hline Transport total & 100 & 100 & 100 & 100 & 100 \\
\hline railway & 55,8 & 59,4 & 58,3 & 54,5 & 52,6 \\
\hline marine & 0,8 & 1,1 & 1,1 & 0,7 & 0,8 \\
\hline river & 0,4 & 0,4 & 0,5 & 0,4 & 0,4 \\
\hline road & 14,6 & 15,8 & 15,9 & 16,9 & 17,1 \\
\hline air & 0 & 0 & 0 & 0 & 0 \\
\hline pipeline & 28,3 & 23,1 & 24,1 & 27,4 & 105,4 \\
\hline
\end{tabular}

Source: compiled based on Table 2.

Table 5. Relative level of average transportation distance $\left(\beta_{1}\right)$.

\begin{tabular}{|l|c|c|c|c|c|}
\hline & 2013 & 2014 & 2015 & 2016 & 2017 \\
\hline Transport total, km on average & 937 & 1057 & 1027 & 962 & 1087 \\
\hline railway & 0,54 & 0,51 & 0,54 & 0,57 & 0,52 \\
\hline marine & 1,0 & 1,37 & 1,11 & 0,87 & 1,16 \\
\hline river & 0,52 & 0,41 & 0,48 & 0,42 & 0,36 \\
\hline road & 0,05 & 0,05 & 0,05 & 0,06 & 0,6 \\
\hline air & 2,94 & 2,88 & 2,97 & 3,17 & 3,06 \\
\hline pipeline & 0,95 & 0,78 & 0,81 & 0,92 & 0,84 \\
\hline
\end{tabular}

Source: compiled based on Table 3.

A comprehensive analysis of these relationships shows that in general, the freight transport services market consists of transportation at different distances. Therefore, it is important to distinguish the transportation market at relatively short distances $\beta 1 \leq 0,3$, the transportation market at average distances of $0,3 \leq \beta 1 \leq 0,7$ and the market for long distance transportations $0,7 \leq \beta 1 \leq 1,0$.

As you can see, road transport mainly competes in the transportation market at short distances, river and railway in the medium-distance market, and sea, air and pipelines in the market of long-haul transportation. Comparing the distance of transportation of goods by land (rail and road) shows that they differ in many ways in favour of railways. That leads to the fact that, while maintaining a certain comparative presence in the market of transportation (three times as much), the share of rail transport in the market of transportation is significantly higher (8-11 times as much):
$(55.8 / 14.6)-(0.54 / 0.05)=3.8 \times 10.8=41.04$ times in 2013;

$(59.4 / 15.8)-(0.51 / 0.05)=3.8 \times 10.2=38.76$ times in 2014;

$(58.3 / 15.9)-(0.54 / 0.05)=3.7 \times 10.8=39.96$ times in 2015 ;

$(54.5 / 16.9)-(0.57 / 0.06)=3.2 \times 9.5=30.4$ times in 2016 ;

$(52.6 / 17.1)-(0.52 / 0.06)=3.1 \times 8.6=26.66$ times in 2017.

However, it should be noted that within the years from 2013 to 2017, rail transport is inferior to the share of the freight market in favour of the automobile (the index is reduced from 41.04 in 2013 to 26.66 in 2017). Moreover, these changes in favour of road transport occur both in cargo transportation and in relation to the average distance of transportation, which in general leads to a decrease in the gap in their shares in the market of freight transport. 
The analysis of the freight transport market will not be complete without the assessment of all indicators in the dynamics. Analyzing the dynamics of the freight transport market, we note that the sharp fall in the country's external commodity turnover in 2014, and, accordingly, the volumes of cargo transportation in subsequent years by $9-18 \%$ (Table 1) and freight turnover $9-15 \%$ (Table 2) in comparison with 2013 was due to a decrease in exports and imports from Russia.

This reduction was not compensated by other countries. In 2013, the volume of cargo turnover with
Russia was 38.3 billion dollars, in 2017 this figure amounted to 11 billion dollars, the fall was $75 \%$. With other countries foreign trade turnover has changed very insignificantly and in the general dynamics of the volume of turnover in billion dollars it decreased in 2017 by $33.8 \%$ compared to 3 in 2013 (Fig. 1). Accordingly, about one third of the capacity in logistics remained unoccupied, especially those who carried goods to Russia, Belarus and other CIS countries.

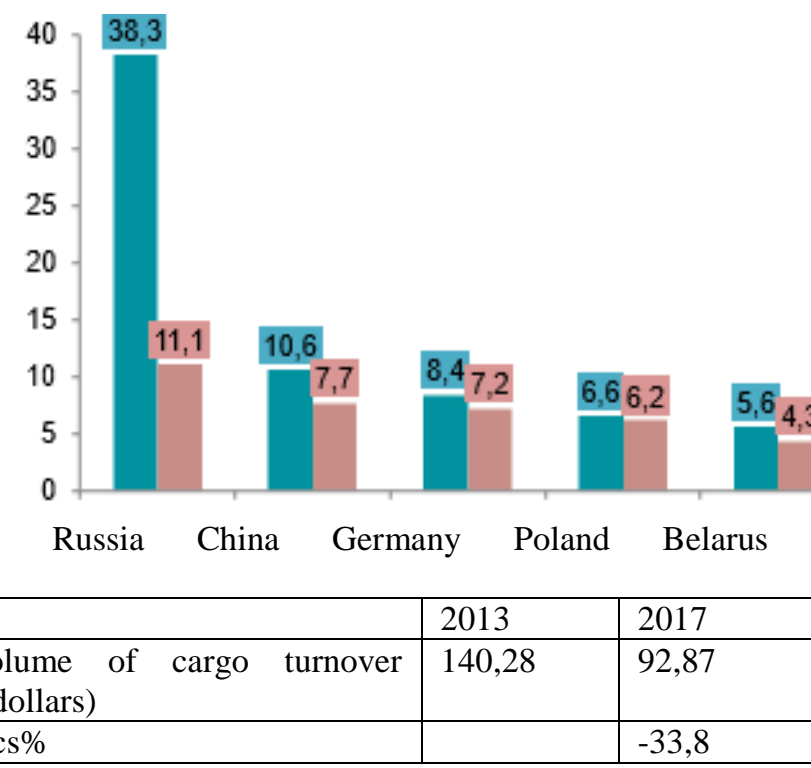

Fig. 1. Analysis of cargo transportation volumes in 2013-2017

Source: State data. Statistics Service of Ukraine for the relevant years.

Despite the reduction of the turnover of goods, the volume of transport services implemented in the country is increasing. Due to the growth of wholesale and retail trade turnover and industrial production, in 2017 the volume of transport services market in Ukraine increased by $14 \%$, and for the first half of 2018 it was $16.8 \%$ compared to the same indicator in 2017 (Figure 2).

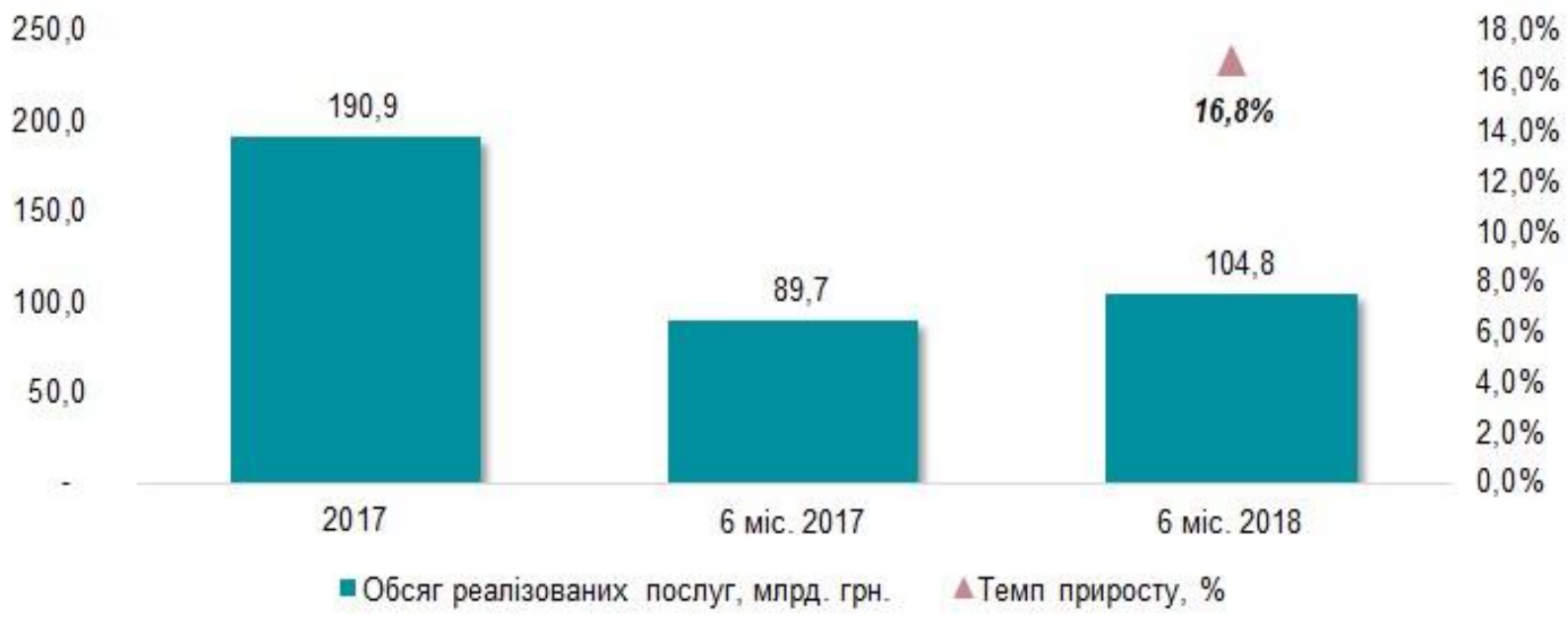

The volume of the services given, billion UAH

Growth rate, \%

Fig. 2. Dynamics of the transport services market in Ukraine in general in $2017-6$ months 2018 biennium, billion UAH.

Source: State data. Statistics Service of Ukraine for 2017-2018.

If we consider the changes that took place in 20162017 in the structure of freight traffic, then the growth in the structural dynamics of goods transported by road should be noted (Figure 3) 


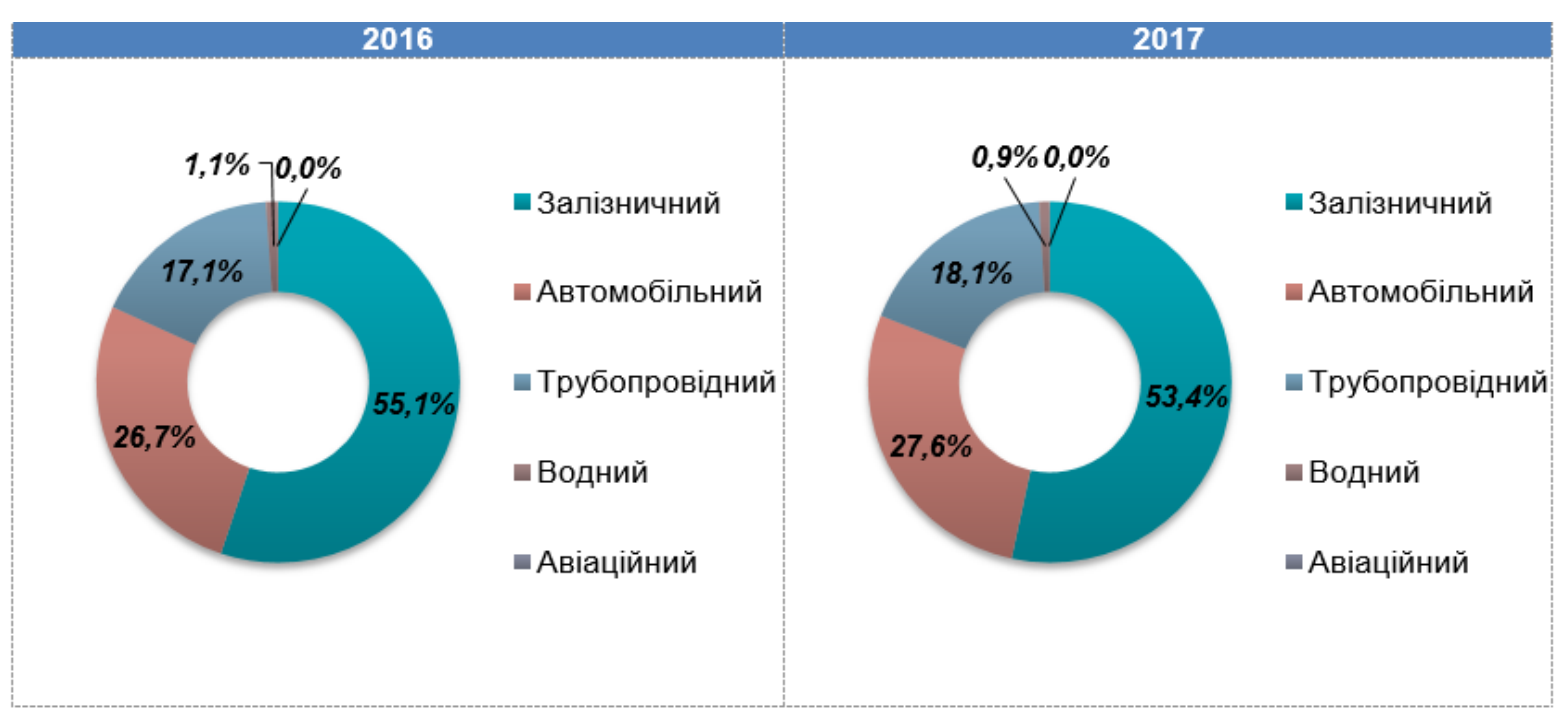

Fig. 3. Dynamics of the structure of freight traffic in Ukraine by modes in 2016-2017, million tons.

Source: State data. Statistics Service of Ukraine for the relevant years.

The reasons for such an increase are, first of all, the entry of large foreign companies into the market and the increase of investments in the development of road infrastructure, as well as a significant increase in tariffs for rail transport.

At the same time, we note a number of problems that have been disturbed in the past and continue to prevent the transport industry to develop to the full extent. The main problem of the road haulage market in Ukraine remains the poor quality of road surfaces. According to "Ukravtodor", by the end of 2016 in Ukraine, $97 \%$ of roads were in a miserable condition. But not only roads complicate life of auto-carriers, but also the lack of financing by the state and no access to financial markets (the availability of leasing programs for the purchase of cars at low annual rates, loans) and rising fuel prices. It is impossible not to mention the size and weight control and restrictions on carriage by weight. As reported in Ukrtransbezpeka, in 2017, about 114 thousand cars were checked, 4 thousand of which were overloaded.

Another of the unresolved problems for road transportation in 2016-2018 is the change of goods delivery routes. Due to the suspension of the FTA between RF and Ukraine and other trade and transport restrictions, numerous transit routes have been amended. In particular, in 2016, Kazakhstan recommended that operators carrying out road freight traffic from Ukraine make new routes through Georgia, Azerbaijan, Turkey, Iran, Turkmenistan and Uzbekistan.

\section{Conclusions}

1. The state of the freight transport market in Ukraine depends on three main factors. They are foreign trade turnover, gross domestic product and production. When all these indicators grow, logistics also develops along with transport in the line of ascent.

2. The analysis of the freight transport market indicates that it is heterogeneous and can be segmented by quantity, cargo turnover and transportation distances. In terms of the number of transported cargoes, road transport prevails (67 to $71 \%$ of the total number of transported cargoes); according to the indicator of cargo turnover, railway transport is the leading part in the total cargo turnover ranging from 54 to 59\%; by transportation distances, an absolute leader is air transport (48-53\% of the total distance travelled).

3. A comprehensive analysis of these relationships shows that in general, the freight transport services market consists of transportation at different distances. Therefore, it is important to distinguish the transportation market at relatively short distances $\beta 1 \leq 0,3$, the transportation market at average distances of $0,3 \leq \beta 1 \leq 0,7$ and the market for long distance transportations $0,7 \leq \beta 1 \leq 1,0$. In the transportation market, road transport mainly competes at short distances, river and railway in the medium-distance market, and sea, air and pipelines in the market of long-haul transportation.

4. The results of the analysis of the freight traffic market in the dynamics show that starting from 3 of 2014, due to a decrease in exports and imports with Russia (by 75\%), a sharp drop in the country's external commodity turnover and, accordingly, the volumes of transported goods in subsequent years by $9-18 \%$ and cargo turnover $9-15 \%$. However, due to the growth of wholesale and retail trade turnover and industrial production in the domestic market of the country in 2017, the transport services market in Ukraine increased by $14 \%$, and for the first half of 2018 , by $16.8 \%$ compared to the same indicator in 2017.

\section{References}

1. Allen J., Browne M., T. (2012). Cherrett Investigating relationships between road freight transport, facility location, logistics management and urban form, Journal of Transport Geography. № 24. 4557.

2. Efimenko A. G. (2011). Formation and transportation services market development: Monograph. Warsaw. Ed. ITP. 187. 
3. Hirschey M. (1985). Market Structure and Market Value The Journal of Business. Vol. 58, No 1 (Jan., 1985), 89-98.

4. Mogilevkin I. M. (2005). Transport and Communications: Past, Present, Future. Moscow0, Nauka. 357.

5. Parubets O. M. (2018). Research on problems and development prospects of transport services export in Ukraine. Scientific notes of the National University of Ostroh Academy. Ostroh: NauOAO. No. 9 (37). 21-24.

6. Popovych P. V., Shevchuk O. S., Matviishin A. Y., Lototska V. M. (2016). Research on tendencies of the road haulage market development in modern conditions. Bulletin of the Zhytomyr State Technological University. No. 2. 224-229.

7. Zamlynskiy V. A., Koval V. V., Kotlubay V. O. (2017). Status and development prospects of export potential of the motor transport services market. Economics and Society. No. 9. 210-214.

\section{Список літератури}

1. Allen J., Browne M., T. Cherrett Investigating relationships between road freight transport, facility location, logistics management and urban form, Journal of Transport Geography. № 24. 2012. 45-57.

2. Efimenko A. G. Formation and transportation services market development: Monograph. Warsaw. Ed. ITP. 2011. p.187

3. Hirschey M. Market Structure and Market Value The Journal of Business. Vol. 58, No. 1 (Jan., 1985), 8998.

4. Mogilevkin I. M. Transport and Communications: Past, Present, Future. Moscow. Nauka, 2005 , p. 357.

5. Parubets O. M. Research on problems and development prospects of transport services export in Ukraine. Scientific notes of the National University of Ostroh Academy. Ostroh: NauOAO 2018 No. 9 (37). pp. 21-24.

6. Popovych P. V., Shevchuk O. S., Matviishin A. Y., Lototska V. M. Research on tendencies of the road haulage market development in modern conditions. Bulletin of the Zhytomyr State Technological University. 2016. No. 2. pp. 224-229.

7. Zamlynskiy V. A., Koval V. V., Kotlubay V. O. Status and development prospects of export potential of the motor transport services market. Economics and Society. 2017. No. 9. pp. 210-214.

\section{АНАЛІЗ РИНКУ ВАНТАЖНИХ ПЕРЕВЕЗЕНЬ В УКРАЇНI \\ О. М. Загурський}

Анотація. Транспортні організації виступають на товарних галузевих ринках суб'єктами пропозиції специфічного товару - транспортні послуги, які формують власний ринок вантажних перевезень, який накладається на інші ринки. Стан ринку вантажних перевезень в Україні залежить від трьох основних чинників. Це зовнішньоторговельний оборот, валовий внутрішній продукт і виробництво.
Коли всі ці показники зростають, логістика також розвивається, а разом 3 нею по висхідній лінії піднімається і транспорт.

В статті проведено комплексний аналіз ринку вантажних перевезень в Україні. Статистичне дослідження перевезень продукції галузей економіки показує, що відстань перевезень вантажів визначається характером розподілу в просторі виробництва конкретних видів продукції вантажообігу, як показника сумарного переміщення вантажів 3 урахуванням їх маси i відстані переміщення.

Результати аналіз ринку вантажних перевезень свідчить, що він неоднорідний i може бути сегментований за кількістю, вантажообігом та відстанню перевезень.

Ключові слова: вантажі, перевезення, ринок, товарообіг, транспортні послуги.

\section{АНАЛИЗ РЫНКА ГРУЗОВЫХ ПЕРЕВОЗОК В УКРАИНЕ \\ О. Н. Загурский}

Аннотация. Транспортные организации выступают на товарных отраслевых рынках субъектами предложения специфического товара транспортные услуги, формирующие собственный рынок грузовых перевозок, который накладывается на другие товарные рынки. Состояние рынка грузовых перевозок в Украине зависит от трех основных факторов. Это - внешнеторговый оборот, валовой внутренний продукт и производство. Когда все эти показатели растут, логистика также развивается, а вместе с ней по восходящей линии поднимается и транспорт.

В статье проведен комплексный анализ рынка грузовых перевозок в Украине. Статистические исследования перевозок продукции отраслей экономики показывают, что расстояние перевозок грузов определяется характером распределения в пространстве производства конкретных видов продукции грузооборота, как показателя суммарного перемещения грузов с учетом их массы и расстояния перемещения.

Результаты анализа рынка грузовых перевозок свидетельствуют, что он неоднороден и может быть сегментирован по количеству, грузообороту и расстояниям перевозок грузов.

Ключевые слова: грузы, перевозки, рынок, товарооборот, транспортные услуги.

\section{O. M. Zagursky ORCID 0000-0002-5407-8466.}

